\title{
Jatropha curcas L: A predominant Panacea for Energy Security and Climate Change
}

\author{
ARUN CHAVAN*, V. K. GOUR and HUSSAIN BASHA \\ *Department of Genetics and Plant Breeding, Institute of Agriculture Science, \\ Banaras Hindu University, Varanasi-221005, India. \\ Department of Plant Breeding and Genetics, \\ Jawaharlal Nehru Krishi Vishwa Vidyalaya, Jabalpur-482004, India.
}

http://dx.doi.org/10.12944/CWE.9.1.19

(Received: February 02, 2014; Accepted: March 13, 2014)

\begin{abstract}
The paper considers Jatropha plant as alternative source of biofuel and sustainable option to mitigate damages caused by climate change on environment. As nonrenewable sources of energy gets depleted other sources starts to unearth by considering all techniques prevailing today. Though Jatropha is under domestication and there are number of constrains that hindering its improvement, it is most viable and widely accepted biodiesel producing species. Being very less demanding plant there is knowledge gaps that concerning the best production practices and the potential benefits and risks to the environment. The certain breeding objectives specific to yield enhancement and stability needs to consider. Critical assessment of prevailing germ plasm and development of new variability for important traits like oil (content and quality) could be further goal for planned breeding strategies. All the uses of this drought tolerant species have to studied clearly to reveal future breeding programme. Genetic improvement using conventional and molecular breeding approaches has to be increased at more places and integrated with latest biotechnological techniques for reducing time and increasing efficiency of breeding.
\end{abstract}

Key words: Jatropha, Energy security, Biofuel, Non toxic Jatropha and Genetic improvement.

\section{INTRODUCTION}

It is not very common to hear states and their leaders criticized for mixing "oil and politics." Oil together with coal and natural gas supply about $88 \%$ of the world's energy needs. Crude oil prices are likely to increase over the long term as fossil reserves diminish and global demand increases, particularly in the newly emerging economies of Asia and Latin America. In view of growing interest for renewable energy sources, liquid bio-energy production from vegetable oils is one of the possible options to reduce greenhouse gas (GHG) emissions and face the concerns of climate change. Bio-diesel production from vegetable oils during 2004-2005 was estimated to be 2.36 million tones globally. Of this, EU countries (1.93 million tonnes) with expectation of $30 \%$ annual increase and the USA ( 0.14 million tonnes) together accounted for $88 \%$ and rest of the world (0.29 million tonnes) for the remaining $12 \%{ }^{1}$. Biofuel production also impacts the environment through its effect on water resources and biodiversity. Declining availability of water for irrigation, most notably in India and China, necessitates using the most water-efficient biofuel crops and cropping systems for long-term sustainability. The use of degraded land, conservation agriculture techniques with minimal soil disturbance and permanent soil cover, intercropping and agro forestry systems will lessen negative environmental impact. Global bio-diesel production is set to grow at slightly higher rate than bio-ethanol and will reach 24 billion litres by being the largest share in 20172. However, shortage of raw material to produce bio-diesel is a major constraint $^{3}$. The total number of oil-bearing species range from 100 to 300 , and of them 63 belonging to 30 plant families hold promise for bio-diesel 
production4. Since the surge of interest in renewable-energy alternatives to liquid fossil fuels hit in 2004-5, the possibility of growing Jatropha curcas L. for the purpose of producing biofuel has attracted the attention of investors and policymakers worldwide. The seeds of Jatropha contain non-edible oil with properties that are well suited for the production of biodiesel; besides that nontoxic variety of Jatropha could be a potential source of oil for human consumption, and the seed cake can be a good protein source for humans as well as for livestock.

Energy demand in the contemporary world has been increased by many folds. So In 2008, Jatropha was planted on an estimated 900 000 ha globally -760000 ha (85 percent) in Asia followed by Africa with 120000 ha and Latin America with 20000 ha. More than 85 percent of Jatropha plantings are in Asia, chiefly Myanmar, China Indonesia and India. The largest producing country in Asia is Indonesia. In Africa, Ghana and Madagascar will be the largest producers. Brazil will be the largest producer in Latin America. Government of India launched "National Mission on Bio-diesel" with a view to find a cheap and renewable liquid fuel based on vegetable oils ${ }^{5}$. The area planted to Jatropha is projected to grow 12.8 million ha by 20156 . There are many knowledge gaps concerning the best production practices and the potential benefits and risks to the environment. Equally troubling is that the plant is in an early stage of domestication with very few improved varieties. Identifying the true potential of Jatropha requires separating the evidence from the hyped claims and half-truths. Keeping these views here we tried to discuss the importance of Jatropha as energy plant and its other sustainable uses.

\section{Jatropha: Origin and Taxonomy}

The physic nut tree (Jatropha curcasL.), originated in Central America and is today found throughout the world in the tropics. It belongs to the family of Euphorbiaceae and is very undemanding in terms of climate and soil. It spread beyond its original distribution because of its hardiness, easy propagation, drought endurance, high oil content, low seed cost, short gestation period, rapid growth, adoption to wide agro-climatic condition, bushy/ shrubby nature and multiple uses of different plant parts ${ }^{7}$. Linnaeus ${ }^{8}$ was the first to name the physic nut Jatropha curcas L. The genus name Jatropha derives from the Greek word jatr'os (doctor) and troph'e (food), which implies its medicinal uses. According to Dehgan and Webster and SchultzeMotel, the genus Jatropha belongs to tribe Joannesieae of Crotonoideae in the Euphorbiaceae family, and contains approximately 175 known species ${ }^{9-10}$. Dehgan and Webster revised the subdivision made by $\mathrm{Pax}^{11}$ and now distinguish two subgenera (Curcas and Jatropha) of the genus Jatropha, with 10 sections and 10 subsections to accommodate the Old and New World species. The tree has maximum height of five meters and requires between 500 and $600 \mathrm{~mm}$ of rainfall. However, the minimum is highly dependent on local conditions. In times of drought, the plant sheds most of its leaves in order to reduce water loss. Flowering occurs during the wet season ${ }^{12}$ often with two flowering peaks, i.e. during summer and autumn. Flowers are unisexual, monoeceious, greenish yellow colored interminal long, peduncled paniculate cymes. The high fruit setting under open pollination revealed that the plant is capable of producing fruits through selfing and cross-pollination. Such a breeding system represents facultative cross-pollination ${ }^{13}$.

\section{Current uses}

In the first half of the 20th century, the export of physic nuts comprised a large share of total exports from Cape Verde. Today, the Jatropha plant is not economically significant in any country, but is used conventionally for numerous purposes:

\section{Soil stabilization}

It is drought resistant plant that has very few demands on its environment which fix the micro environment of soil.

\section{Enclosure of fields}

The physic nut is being planted in both Africa and Asia as chief hedges around gardens and fields

\section{Traditional human and animal medicine}

Oil and plant parts are used as wound disinfectant, purgative, rheumatism and against skin diseases etc. 


\section{Biological pesticide}

Also used insecticide and molluscicide to control insect damage.

\section{Soap production}

From the oil of the seeds

\section{Fertilizer}

The press cake can be used as highnitrogen fertilizer

\section{Energetic use of the physic nut}

Oil of the physic nut as fuel (motor, lamp, and cooker oil); entire plants and especially the fruit as biogenic solid fuel also as lubricating fluid for motors

\section{To reduce erosion}

It can be planted to reduce erosion caused by water and/or wind and also to demarcate the boundaries of fields and homesteads

\section{Shade and support}

Jatropha plants are used as a source of shade for coffee plants in Cuba; whereas in Comore islands, in Papua New Guinea and in Uganda used as a support plant for vanilla plants.

\section{Potential feed for human and animals}

The non-toxic variety of Jatropha from Mexico can be a suitable alternative to the toxic Jatropha varieties. Which could be a potential source of oil for human consumption, and the seed cake can be a good protein source for humans as well as for livestock ${ }^{14}$. Varieties commonly found growing in Africa and Asia has seeds that are toxic to humans and animals, whereas some varieties found in Mexico and Central America are known to be non-toxic. Keeping in view the seeds of these non-toxic varieties have been sent to Nicaragua, Zimbabwe, Mexico and India for cultivation through traditional and tissue culture techniques and comparison for yield, resistance to diseases, survival and nutrient requirements with the toxic varieties of the region. The press cake of physic nut for animal feed was investigated and proved in advisable15.

\section{Potential medicinal value}

The Jatropha has medicinal value in constipation (seeds); wound healing (sap); against malaria (leaves); etc.

Use of the wood is limited, because Jatropha provides poor quality fire wood. Because it is very soft, it is used as weaving material. It can also be planted under the poverty alleviation programs that deal with land improvement.

\section{Status of genetic improvement}

Genetic variation among known Jatrophaaccessions may be less than previously thought, and breeding inter-specific hybrids may offer a promising route to crop improvement. Very little is known about Jatropha genome. Chromosomes are of very small size (bivalent length 1-3.67 $\mathrm{lm}$ ) with most species having $2 \mathrm{n}=$ 22 and base number of $x=11^{16}$. It is attractive candidate for genome sequencing with genome size (1C) to be $416 \mathrm{Mbp}^{17}$. Breeding to raise oil yields became a focused area of research with the 2004/5 surge in interest in Jatropha - an effort led mainly by the private sector. Given the time required for promising accessions to mature and be evaluated, it is clear that work to improve yields through breeding is at a very early stage and that present plantations comprise, at best, marginally improved wild plants. Increasing oil yield must be a priority an objective that has only recently been addressed by private enterprise. The objectives for genetic up gradation of the crop should aim at more number of female flowers or pistillate plants, high seed yield with high oil content, early maturity, resistance to pests and diseases, drought tolerance/ resistance, reduced plant height and high natural ramification of branches. In addition to these targets, genetic improvement in general characteristics and methyl ester composition to make it more suitable for bio-diesel production18 reported that genetic improvement and domestication of Jatropha should follow the same course as that of castor (Ricinus communis L.) belongs to the same family. Castor has been improved from a perennial wild to annual domesticate, having short internodes with varying flower sexuality ratios from completely pistillate to predominantly male types ${ }^{19}$.

Comprehensive work on collection, characterization and evaluation of germplasm for growth, morphology, seed characteristics and yield 
traits is still in its infancy. Regardless of the number of accessions used, the robustness of the primer and number of marker data points, all accessions from India clustered together. In general, diversity analysis with local germplasm revealed a narrow genetic base in India ${ }^{20}$ and south China ${ }^{21}$, indicating the need for widening the genetic base of Jatropha through introduction of accessions with broader geographical background and creation of variation through mutation and hybridization techniques. Hence a large scale collection of germplasm from selected plus trees, their conservation and the evaluation program of various Jatropha accessions is essential to understand patterns of variability. Molecular diversity estimates combined with the data sets on other agronomic traits will be very useful for selecting the appropriate accessions. In spite of numerous favorable attributes, the full potential of the crop has not been realized due to lack of planned breeding programs for creation of new and improved verities. Ones genetically distinct verities has been identified, these will serve as important source of cultivation of Jatropha under varying climatic conditions and development of new varieties through breeding. Molecular breeding can be used as useful tool to monitor sequences of variation and create new genetic variation by introducing new favorable traits from landraces and related species. The certain breeding objectives specific to yield enhancement needs to considered like; improve dry matter distribution, with greater emphasis to fruits rather than vegetative parts, Synchronous maturity, increased flowering, branches, number of fruits, seed weight, seed oil content and development of non toxic verities.

Genetic improvement using conventional breeding approaches has to be initiated at more places and integrated with latest biotechnological techniques for reducing time and increasing efficiency of breeding. Potential of the new varieties developed has to be further tested for their performance, through multilocation trials. Development of techniques such as, somaclonal variants, mutations, doubled haploids, and gene transfer which support plant breeding activities should be emphasized.

\section{Biofuel for energy security and environmental impact}

The scarcity of conventional fossil fuels, growing emissions of combustion-generated pollutants, and their increasing costs will make biomass sources more attractive ${ }^{22}$. For the reason of edible oil demand being higher than its domestic production, there is no possibility of diverting this oil for production of bio-diesel. Biodiesel fuels are attracting increasing attention worldwide as a blending component or a direct replacement for diesel fuel in vehicle engines. An alternative fuel to petro-diesel must be technically feasible, economically competitive, environmentally acceptable, and easily available. The current alternative diesel fuel can be termed biodiesel. Biodiesel can offer other benefits, including reduction of greenhouse gas emissions, regional development and social structure, especially to developing countries ${ }^{23}$.

There are many tree species which bear seeds rich in oil. Of these some promising tree species have been evaluated and it has been found that there are a number of them such as Jatropha and Pongamia ('Honge' or 'Karanja') which would be very suitable in our conditions. However, Jatropha has been found most suitable for the purpose. The by products of Bio-diesel from Jatropha seed are the oil cake and glycerol which have good commercial value. These by products shall reduce the cost of biodiesel depending upon the price which these products can fetch. The cost components of bio-diesel are the price of seed, seed collection and oil extraction, oil trans-esterification, transport of seed and oil. The cost of bio-diesel produced by trans-esterification of oil obtained from Jatropha seeds will be very close to the cost of seed required to produce the quantity of biodiesel as the cost of extraction of oil and its processing in to biodiesel is recoverable to a great extent from the income of oil cake and glycerol which are by products. Using non-toxic varieties from Mexico could make greater use of this potentially valuable by-product, but even these varieties may need treat mentto avoid sub-clinical problems that could arise with long-term feeding of Jatropha seed cake to livestock ${ }^{24}$. 
The carbon sequestration effect of Jatropha plantations seems to play an important role in the financing of these large projects. In addition, biodiesel produces fewer particulates, hydrocarbons, nitrogen oxides and sulphur dioxides than mineral diesel and therefore reduces combustion and vehicle exhaust pollutants that are harmful to human health. The need to slow or reverse global warming is now widely accepted. This requires reduction of greenhouse gas (GHG) emissions, especially reduction of carbon dioxide emissions. Using cultivated and non-domesticated plants for energy needs instead of fossilized plant remains such as mineral oil and coal reduces the net addition of $\mathrm{CO} 2$ to the atmosphere. In addition, biodiesel produces fewer particulates, hydrocarbons, nitrogen oxides and sulphur dioxides than mineral diesel and therefore reduces combustion and vehicle exhaust pollutants that are harmful to human health. Fargione et al. found that converting rain forest, peatlands, savannahs or grasslands to the growing of biofuel cropsreleases 17 to 420 times more CO2 than the reductions that occur when these biofuels replace fossil fuels ${ }^{25}$. This under scores the fact that growing Jatropha on degraded wastelands with minimal fertilizers and irrigationwill have the most positive environmental impact.

\section{Constrains that affect domestication and improvement}

Plantation of Jatropha on large scale by farmers or any organization faces numerous constrains that affect the growth of Jatropha industry and which get to be commercialized. The some constrains are pointed here:

- High yielding verities yet to e developed

- $\quad$ Plant to plant variation in yield, oil content and oil quality

- $\quad$ Lack of info about agronomic package of practices of reliable yield

- Poor assessment of environment risk benefit potential

- It takes 3-5 years for maturity higher than annual oilseed crop

- $\quad$ Toxic genotypes not safe as feedstock

- Wood is of poor quality for burning and construction

- Can't tolerate frost and water logging condition
- It may become weedy plant in certain climatic condition

- $\quad$ There is limited information available on genetics and agronomy of Jatropha

- Lack of planned improvement program globally

- Currently focused is on domestication of the species

- Lack of bench mark descriptors and information on genetic variability, effects of environment and genotype $\mathrm{x}$ environment $(\mathrm{G} \times \mathrm{E})$ interaction ${ }^{26}$.

- Jatropha oil has higher viscosity than mineral diesel, although this is less of a problem when used in the higher temperature environment of tropical countries.

Plant breeders working on Jatropha are now using modern genetic marker techniques that speed up the screening process, but these selections still need to be grown to maturity for validation.

\section{CONCLUSION}

There is an urgent need to understand more about Jatropha in general and its possible application and its performance in larger plantations. This requires an interdisciplinary approach covering Jatropha systems and their determining and limiting factors. In addition, breeding programs and selection tools need to be developed to provide appropriate plant material for different agro-ecosystems. At the global level, there is a need for coordination of biofuel development and an international food reserve system to protect the vulnerable poor. The development of non-toxic varieties should be a priority. The integration of the available scattered knowledge on and experiences with crop performance of different provenances in different environments and management interventions is essential. The expectation that Jatropha can substitute significantly for oilim ports will remain unrealistic unless there is an improvement in the genetic potential of oil yields and in the production practices that can harness the improved potential. Although Jatropha is well known for having wide adaptability and plethora of uses its full potential is far from being realized. Improved varieties with desirable traits for specific 
growing conditions are not available, which makes growing Jatropha a risky business. Hence, Jatropha can be improved through assessment of variation in wild sources and selection of superior/elite genotypes attributes, added to the benefits of using a renewable fuel source, can contribute in an even larger way to protecting the environment.

\section{REFERENCES}

1. Parikh J.Growing our own oils. Biofuels India; 3(3): 7 (2005).

2. OECD-FAO. Agricultural outlook 2008-2017: (2008).

3. Wani S. P.,Sreedevi T. K., Reddy B. V. S. Biofuels: status, issues and approaches for harnessing the potential. Hyderabad, India.(2006).

4. Hegde D. M. Tree oilseeds for effective utilization of wastelands. In: Compendium of lecture notes of winter school on wasteland development in Rainfed areas, Central Research Institute for Dry land Agriculture, September 1-30, Hyderabad, India; 2003: 111-9. ( 2003)

5. Shukla S. K. Experiences of Chattisgarh biofuel development authority. Biofuels India; 3(4): 12-3 (2005).

6. Gexsi. Global Market Study on Jatropha. Final Report. Prepared for the World Wide Fund for Nature (WWF). London/Berlin: Global Exchange for Social Investment. (2008.)

7. Kumar A. and Sharma S. An evaluation of multipurpose oil seed crop for industrial uses (Jatropha curcas L.): a review. Ind Crops Prod; 28(1): 1-10(2008)

8. Linnaeus C. Species plantarum. In: Jatropha. Impensis Stockholm: Laurentii Salvii;p. 1006-7. (1753)

9. Dehgan B. and Webster GL. Morphology and infrageneric relationships of the genus Jatropha (Euphorbiaceae). University of California Publications in Botany. (1979)

10. Schultze-Motel J. Rudolf Mansfelds Verzeichnis land wirts chaftlicher and gärtnerischer Kulturpflanzen (ohne Zierpflanzen). Berlin: Akademie-Verlag. (1986).

11. Pax F. Euphorbiaceae-Jatropheae. In: Engler A, editor. Das Pflanzenreich IV, vol. 147(42). Leipzig: Verlag von Wilhelm Engelmann.(1910)
12. Raju A. J. S. and Ezradanam V. Pollination ecology and fruiting behaviour in a monoecious species, Jatropha curcas L. (Euphorbiaceae). Curr Sci; 83: 1395-8. (2002)

13. Dhillon R. S. , Hooda M. S. , Handa A. K., Ahlawat K. S. , Kumar Y., Subhash, et al. Clonal propagation and reproductive biology in Jatropha curcas L. Indian J Agroforest; 8(2):18-27(2006)

14. Becker, K., Makkar, H.P. S. Toxic effects of Phorbol esters incarp (Cyprinus carpio L.). Vet. Human Toxicol. 40: 82-86(1998.)

15. BÖHME H.Möglichkeiten der Verwendung von Pressrückständen der Purgiernuss in der Tierernährung auf den Kap Verden.Institut für Tierernährung der Bundesforschungsanstalt für Landwirtschaft, Braunschweig. (1988)

16. Soontornchainaksaeng $P$, Jenjittikul $T$. Karyology of Jatropha (Euphorbiaceae) in Thailand. Thai For Bull; 31: 105-12(2003)

17. Carvalho C. R., Clarindo W. R., Praça M. M., Araújo F. S. and Carels N. Genome size, base composition and karyotype of Jatropha curcas L., an important biofuel plant. Plant Sci; 174: 613-7(2008)

18. Sujatha M., Reddy T. P. and Mahasi M. J. Role of biotechnological interventions in the improvement of castor ( Ricinus communis L.) and Jatropha curcas L. Biotechnol Adv; 26: 424-35. (2008)

19. Singh D. Castor Ricinus communis (Euphorbiaceae). In: Simmonds NW, editor. Evolution of crop plants. London: Longman; 84-6. (1976)

20. Ganesh Ram S., Parthiban K. T., Kumar R. S., Thiruvengadam V. and Paramathma M. Genetic diversity among Jatropha species as revealed by RAPD markers. Genet Resour Crop Evol doi:10.1007/s10722-0079285-7. (2008)

21. Sun Qi-Bao, Li Lin-Feng, Li Yong, Wu Guo- 
Jiang and Ge Xue-Jun. SSR and AFLP markers reveal low genetic diversity in the biofuel plant Jatropha curcas in China. Crop Sci; 48: 1865-71(2008)

22. Sensoz S., Angin D. and Yorgun S. Influence of particle size on the pyrolysis of rapeseed (Brassica napus L.): fuel properties of biooil. Biomass Bioenergy; 19: 271-9(2000).

23. Demirbas A. and Demirbas I. Importance of rural bioenergy for developing countries. Energy Convers Manage; 48: 238698(2007)

24. Makkar, H. P. S. and Becker, K.Potential of Jatropha curcas seed meal as a protein supplement to livestock feed, constraints to its utilization and possible strategies to overcome constraints. In: Biofuels and Industrial Products from Jatropha curcas. Edited by: G. M. Gubitz, M. Mittelbach \& M. Trabi. Developed from the February 23-27, 1997 Symposium "Jatropha 97", Managua, Nicaragua. (1997).

25. Fargione, J., Hill, J., Tilman, D., Polasky, S. and Hawthorne, P. Land Clearing and the Biofuel Carbon Debt. Science, 319: 12351238(2008.)

26. Jongschaap R. E. E., Corre' W. J., Bindraban P. S. and Brandenburg W. A. Claims and facts on Jatropha curcas L. Wageningen, The Netherlands: Plant Research International.(2007). 